\title{
Kırsal Kalkınmada Kültürel Ekoloji Yaklaşımı: Isparta İli Eğirdir İlçesi Göktaş Mahallesi Uygulaması
}

DOI: $10.26466 /$ opus.749822

\author{
Şekibe Şanal ${ }^{*}$ - Fatma Handan Giray ** \\ * Ziraat Yüksek Mühendisi, Isparta Uygulamalı Bilimler Üniversitesi, Lisansüstü Enstitüsü, \\ Isparta/Türkiye \\ E-Posta: sanalsekibe@gmail.com \\ ORCID: 0000-0002-6012-7535 \\ ** Doç. Dr., Isparta Uygulamalı Bilimler Üniversitesi, Ziraat Fakültesi, Isparta/Türkiye \\ E-Posta: $\underline{\text { handan.giray@gmail.com }}$ \\ ORCID: $\underline{0000-0003-4256-9652}$
}

$\ddot{O} z$

Isparta ili Ĕ̆irdir ilçesine bağglı olan Göktaş Mahalle'sinin sosyo-ekonomik yapısını kültürel ekoloji yaklaşımı ile analiz etmek amacıyla gerçekleş̧irilen bu çalışmada, Göktaş Mahallesi insan ve ekolojinin etkileşimi açısından ele alınmıştır. Göl etrafında kurulu olan Göktaş'ta hem mahalle sakinlerinin etnik ve kültürel yapısının ekolojiye hem mahallenin ekolojisinin mahalle sakinleri üzerine etkileri değerlendirilmiştir. Çalışma kapsamında kullanılan veriler, ilgili kültürel ekoloji literatürüne dayalı olarak oluşturulan yapılandırılmış görüşme formları ve mahallede iki yıl boyunca düzenli ziyaretler sırasındaki gözlemlerle derlenmiştir. Böylece, mahallenin kültürel ekolojik dokusu ortaya konulmuştur. Özellikleri itibariyle kırsal bir alan olan Göktaş, eskiden köy statüsündeyken 1999 yılında yapılan bir oylama ile mahalle statüsünü, 2018 yılındaki ikinci bir oylama sonucundaysa tekrar "köy" statüsüne geçmiştir. Çalışmanın saha aşamalarının gerçekleştirildiği sırada idari açıdan "mahalle" olması ve 2018 oylamas sonucunun henüz uygulamaya yansımaması nedeniyle makalede de mahalle biriminin kullanılması tercih edilmiştir. Göktaş'ın bölgedeki diğer kırsal alanlardan farklı olarak en büyük dışsal sorunu ve zayıf yanı, civardaki kötü ş̈hretidir. Bunun yenilememesi, halkın Göktaş dışında sosyal, ekonomik ve kültürel iletişimi ve ilişkiyi kurmasını engellemektedir. Çalışma sırasında tespit edilen Göktaş halkının istekliliği ve kamu otoritesinin olumlu girişimleri ile Göktaş'ın genç nüfusu ve birlikte çalışma geleneklerinin güçlü olması özelliklerinden ve etkileyici doğal peyzajının avantajlarından yararlanılarak Göktaş'llların örgütlü bir şekilde tekrar su ürünleri faaliyetlerinde yer alması ve kırsal turizme yönelik faaliyetlerin planlanması uygun görülmektedir.

Anahtar Kelimeler: Göktaş Mahallesi, Eğirdir Gölü, Kültürel ekoloji, Kırsal kalkınma 


\title{
Cultural Ecology Approach in Rural Development: An Emprical Study in Göktaş District of Eğirdir Town of Isparta Province
}

\begin{abstract}
This study was carried out to analyze socio-economic structure of Göktaş neighborhood of Eğirdir district in Isparta province through cultural ecology approach which discussed interactions between human and ecology with particular attention to effects of the changes in the Eğirdir Lake over time on residents of Göktaş in relation to the cultural texture of the neighborhood. The data used in the study were gathered through a structured questionnaire formed based on the relevant cultural ecology literature and observations during regular visits paid to the neighborhood for two years. Thus, cultural ecological texture of the neighborhood was revealed. Although Göktaş is a rural area in terms of its characteristics, it has been a "neighborhood" administratively during the study and became again a village through a ballot initiative in 2018. Unlike other rural areas in the region, the biggest external problem of the people in Göktaş and its weakness is its bad fame and prejudices in the region. As long as it does not overcome, it will not be possible for Göktaş people to establish an adequate social, economic and cultural communication and relationship other than Göktaş. It was determined during the study that there are willingness of the people of Göktaş and positive initiatives of the public authority. Taking advantage of these facts together with the young population of Göktaş, strong traditions of working together, and amazing landscape, it is suggested for Göktaş to be re-involved in aquaculture activities and to plan rural tourism activities in an organized way.
\end{abstract}

Keywords: Göktaş Neighborhood, Eğirdir Lake, Cultural ecology, Rural development 


\section{Giriş}

\section{Kavramsal Zemin}

Bu çalışmanın ana amacı, insan ve çevre arasındaki ilişkileri inceleyen kültürel ekoloji yaklaşımının teorik ve kavramsal çerçevesini kırsal kalkınma açısından tartışmak ve bir alan çalışması ile uygulamaktır. Bunun yanı sıra uygulama alanı olarak seçilen Isparta'nın Eğirdir ilçesine bağlı Göktaş Mahallesi sakinlerinin sorunlarını ve beklentilerini belirleyerek yapılacak kalkınma çalışmalarına bir zemin oluşturmak da bu çalışmanın amaçları arasındadır. Göktaş Mahallesi'nin seçilmesinin nedeni, etnik ve kültürel olarak Isparta ve Eğirdir'den farklı bir yapıya sahip olması, son dönemde ilde değişik kurumlarca Göktaş’a yönelik projeler hazırlanmaya başlanması ve söz konusu hazırlıkların başarılı olabilmesi için doğrudan faydalanıcısı olacak olan mahallelilerin görüş ve isteklerinin bilinmesinin ve plana dâhil edilmesinin zorunlu olduğu ön kabulüdür. Böylece, hem kültürel ekoloji yaklaşımının kırsal alanda bir uygulaması yapılacak hem Göktaş Mahallesi'nde yapılacak kalkınma uygulamalarına bir zemin oluşturulacaktır.

Bu kapsamda öncelikle çalışmanın temel kavramsal çerçevesini oluşturan ekoloji ve kültürel ekolojinin tanımı, tarihçesi ve temel ilkeleri açılanmıştır. Araştırmanın evrenini oluşturan Göktaş Mahallesi sakinlerinin etnik kökeni olan Çingenelerin tarihi ve Çingene kültürü hakkında bilgiler verilmiştir.

Çalışmanın uygulama bölümünde Göktaş Mahallesi'nde yapılan gözlemler, görüşmeler ve anketlerden elde edilen kültürel bulgular açıklanmış ve saha araştırmasından elde edilen veriler analiz edilerek mahallenin altyapı ve kamusal hizmetler ile ilgili bilgileri, sağlık hizmetleri, mahallenin sorunları, istekleri ve beklentileri belirlenip sunulmuştur.

Ekolojinin tanımı: Ekoloji, canlıların birbirleriyle ve maddi çevreleriyle olan çok yönlü ilişkilerini inceleyen; en uygun çevresel koşullar altında yaşayabilmeleri için araştırmalar yürüten bilim dalıdır. Var olan her şey birbirini etkilemekte ve birbirinden etkilenmektedir. Bu etkileşimin sağlıklı olması, ekolojik dengenin bozulmadan devam etmesini sağlamaktır (Feyzioğlu, 2011).

İnsanlar diğer tüm canlılar gibi varoluşundan itibaren çevre ile iç içedirler. Doğa olaylarının çevreye verdiği değişimin insan-çevre ilişkisinde de aynı çerçevede geliştiğini söylemek mümkündür. Bir ormanın yakınında yer alan 
bir göl nasıl ki ormanın ve yer aldığı bölgenin iklimine etkide bulunuyorsa, aynı şekilde doğanın yapısı da insanı ve insan kültürünü doğrudan etkilemektedir.

Ekolojinin tarihçesi üç aşamada özetlenebilir: "Bilinçsiz oluş devri” olarak adlandırılan ilk aşamada insanlar, insan-doğa ilişkilerinin farkında değillerdir. "Bilinçlenme dönemi" olarak adlandırılan ikinci aşama 19. yüzyıldan başlayarak 1965 yılına kadar olan dönemi içine almaktadır. Ondokuzuncu yüzyılın ikinci yarısında insanların doğaya bakış açlarının değişmesine, on sekizinci yüzyılın sonları ve on dokuzuncu yüzyılın başlarında endüstri devrimi ile oluşan sanayileşme neden olmuştur. "Bilinçli oluş dönemi" olarak adlandırılan üçüncü aşama, 1965 yılından bugüne kadar olan zamanı kapsamaktadır. Bu aşama dünyada önemli ekolojik problemlerin ortaya çıtığı ve buna bağlı olarak da doğayı bu problemlerden koruma ve kurtarma arayışlarının gündeme geldiği bir dönemdir (Kocataş, 1997).

Kültürel ekolojinin tanımı: İnsanın fiziki çevresini kullanma şeklini, kültür ve fiziki çevre şartları belirlemektedir. Herhangi bir kültür ile onun doğal çevresi arasındaki çok yönlü etkileşim ve ilişki "kültürel ekoloji” olarak tanımlanmaktadır (Korkmaz ve Gürbüz, 2008).

Çevresel faktörler, insan faaliyetlerini kısıtlayıcı veya teşvik edici olarak etkileyen faktörlerden sadece birisidir; ama belirleyicisi değildir. Bu etkileyen faktörler çevresel ve kültürel faktörler olabilir. İklimin sert veya 1lıman olması, yağış miktarı, kuraklık vb. gibi çevresel faktörler insan faaliyetlerini kısıtlayıc rol oynadığı gibi; siyasal sistemler, diğer toplumlarla olan ilişkiler, teknoloji, inanç sistemleri, sosyal ve ekonomik kurumlar da insan faaliyetlerini ve çevre ile ilişkilerini temelden etkilemektedir (Sutton ve Anderson, 2014).

Kültürel ekolojiyi, insanların bu kadar geniş bir çevreye nasıl uyum gösterdiğini anlamak için bir metodoloji olarak kullanan ilk isim Antropolog Julian Steward'dır. Steward, 1955 yılında yayımladığı Kültürlerin Değişimi Teorisi: Çok Hatlı Doğrusal Evrim Metodolojisi (Theory of Culture Change: The Methodology of Multilinear Evolution) isimli eserinde 'çevreye uyumla kültür değişiminin yaratılma yollarını' sunmuştur. Steward, gerçek kültürlerden çok soyut olarak kültüre bakmanın, kültürel gelişmenin gerçek sürecini aydınlatmayacağını belirtmektedir. Steward'a göre 'doğal yaşam 
alanını kullanan topluluklarda doğal çevrenin gelişen siyasal ve toplumsal yapıların insanın varoluş davranışına büyük bir etkisi vardır olgusu', bu düşüncenin temelini oluşturmaktadır (Steward, 1972).

Kültürel ekoloji, bir toplumun çevresine uyarlanma sürecinin incelenmesidir. Kültürel evrim ve çevresel uyum arasındaki ilişkidir. Kültürel ekoloji, insanın kültürel evrimini açıklarken, fiziksel alan, biyolojik ortam, kültürel ortam içerisinde incelemeler yapmış ve yaşama odaklanmıştır. Steward' a göre kültürel ve sosyal evrim, sadece kültür, gelenek, görenek gibi kavramlar ile incelenebilirse de, insanın yaşadığı, ilişkide bulunduğu çevre ile etkileşimlerin de ele alınması gerekmektedir (Steward, 1972).

Steward, özellikle belli fiziki koşullarda çevreye uyum sağlama ve kaynakları kullanma stratejilerinin kültürü nasıl etkilediği üzerinde durmaktadır. Fiziki çevreye uyum sağlamanın belli davranış şekilleri mi gerektirdiği yoksa bunun çok çeşitli şekillerinin olabileceğini mi araştırarak 'çok hatlı evrim kuramı' nı ortaya koymuştur. Steward' in ortaya attığı bu kurama göre benzer fiziki koşullarda farklı toplumlar çevreye adapte olabilmek için birbirinden çok farklı stratejiler geliştirebilirler ve bu stratejiler o toplumun başarılı veya başarısız olmasını önemli ölçüde etkiler. Böylece benzer fiziki koşullarda gelişim, kültürel seçimlere göre farklı olabilmektedir (Ateş, 2011).

Kültürel ekolojik yaklaşım, ekosistem içerisinde özellikle yiyecek üretimi, barınma ve demografik değişkenlerin doğal kaynaklara yaptığı baskıyı ele alır ve dolayısıyla sürdürülebilirlik önemli bir konu olarak ön plana çıkar. Butzer (1994)'e göre kültürel ekolojistler insanın ekosistem içerisindeki rolü ve doğal kaynakları kontrol etmesini, insanların yaşam biçimlerinin doğaya etkilerini, kültürel davranışların çeşitliliğini ve demografik değişimlerin etkilerini inceler.

Kültürel ekolojide asıl olan; insanın fiziki çevreyi kendisi için kullanması, ancak bu kullanma sırasında fiziki çevrenin kendisini yenilemesine ve var olan ekolojik dengesini sürdürmesine imkân verilmesidir. Farklı kültürler, fiziki çevreden farklı şekillerde yararlanmakta ve buna bağlı olarak farklı kültürel ekolojiler ortaya çıkmaktadır (Korkmaz ve Gürbüz, 2008).

Kültürel ekolojik çalışmalar genellikle küçük toplumları ele almaktadır. Çünkü bu yaklaşımın temel kavramları olan ekoloji, uyum, kültür bölgesi, geçim şekilleri, çevresel denge gibi kavramların en iyi küçük toplumlarda gözlenebileceğine inanılmaktadır. Küçük toplumların içerisinde bulundukları doğal çevreye ve genel anlamda değişimlere ve durumlara uyum 
kabiliyeti, yeni bilgi, teknoloji ve düşünceleri nasıl kabul veya reddettiklerini anlamak, bu tür çalışmaların temel amacıdır (Arı, 2003).

\section{Ekolojinin Temel İlkeleri}

Ekolojiyi diğer bilim dallarından ayıran en önemli özellik, canlı varlıkların bulundukları ve yaşadıkları ortam ile çevresindeki cansız ortam arasındaki ilişkileri "bütüncül" bir yöntem ile inceleyen bir bilim dalı olmasıdır. Bu da insan merkezci düşüncenin reddi anlamına gelmektedir. Bu bütüncül yöntem on temel ilke ile şekillenmiştir. Bu ilkeler aşağıda kısaca açıklanmıştır (Kışlalığlu ve Berkes, 1990):

Doğanın Bütünlü̈̆̈̈ İlkesi: Hayvanı, bitkisi, canlı ve cansız tüm varlıklarıyla doğa bir bütündür ve yaşam için birbirleriyle etkileşim ve dayanışma içindedir.

Doğanın Sınırlılığı İlkesi: Her ne kadar doğanın kendini yenileyebilme yeteneği varsa da çoğalan nüfusu ve kirlilikleri taşıma kapasitesi sınırlıdır ve doğa sonsuz değildir.

Doğanın Özdenetim İlkesi: Ekosistemler, özdenetim ve geri beslenme işlemleriyle bütünlüklerini ve yaşamlarını kendi sınırı içinde korumaya yönelirler.

Doğanın Çeşitliliği İlkesi: Canlılar arasındaki çeşitlilik her biri birbirine bağımlı bir sistem içinde yaşamın sürekliliğini sağlar.

Doğada Hiçbir Şey Yok Olmaz İlkesi: Bu ilke termodinamik yasasına dayanır ve var olan her madde ve enerji bir şekilden başka bir şekle dönüşür fakat hiçbir yolla yok olmaz.

Doğaya Karşı Elde Edilen Her Başarının Bir Bedeli Vardır İlkesi: İkinci termodinamik yasası olan bu ilkeye göre her enerji dönüşümünde enerjinin bir kısmı iş yapamayacak kadar dağınık bir şekle girer.

Doğanın Geri Tepmesi İlkesi: Fizikteki her etkinin bir tepkisi olduğu gerçeğinden hareketle doğa, yapılan müdahalelere karşı koyma gücüne sahiptir. 
En Uygun Çözümü Doğa Bulmuştur İlkesi: Her canlı milyonlarca yıl süren evrim sonucunda en uygun şeklini almıştır ve bu doğanın temel yasası olmuştur.

Kültürel Evrim ve Geleneksel Ekolojiye Saygı İlkesi: Evrim sonucunda son haline gelmiş olan insan, biyolojik evrim sonucunda kültürü yaratmıştır ve bu da bir ekolojik uyumdur.

Doğa ile Birlikte Gitmek IIlkesi: Doğanın kendi içerisinde meydana getirdiği ekolojik döngülerini, mevsimlerini göz önünde bulundurmak gerekir.

Yukarıdaki ilkeler birbirleriyle ilişkilidir. Çünkü doğa kendi kendini denetleyen bir bütündür. İnsanın ileriyi görmeden, bilinçsizce çevresinde yaptığı değişiklikler, bu bütünün çeşitli dengelerini bozmaktadır. Oysa doğaya aykırı değil, doğayla birlikte ya da doğanın suyuna giderek yaşamak bütün için en yararlı yoldur (Kışlalıoğlu ve Berkes, 1990).

\section{Çingenelerin Tarihi Geçmişi ve Kültürü}

Türkiye'de yaşayan birçok kültürel ve etnik gruplardan biri de Çingenelerdir. Çingeneler Anadolu'ya onuncu yüzyılda gelmiş, o günden bu yana da Anadolu halkıyla iç içe yaşamaktadırlar (Ünaldı, 2012).

Anadolu'daki varlığı uzun bir geçmişe dayanan Çingenelerin, Hindistan'dan ayrıldıktan sonra Anadolu'yu bir geçiş noktası ve yaşam alanı olarak seçtikleri bilinmektedir.

Cumhuriyet döneminde ise Lozan Antlaşması çerçevesinde Yunanistan' dan gelen ve sayıları tam olarak belli olmayan bir Çingene nüfusu varlığ söz konusudur. Lozan'da imzalanan 'Nüfus Mübadelesi Sözleşmesi' uyarınca göç eden göçmenlerle birlikte belirli bir oranda Çingene nüfusu da Türkiye'ye gelmiştir (Kolukırık, 2009).

Türkiye'de genellikle bütün yerleşim yerlerinde gerek göçebe gerek yerleşik olarak yaşayan Çingenelere rastlamak mümkündür. Çingeneler, bulundukları yerlerin belirli semtlerin varoşlarında, kenar mahallelerinde, sağlıksız koşullarda yaşamlarını sürdürmeye çalışmaktadırlar. Çingenelerin önemli bir kesimi ise belirli güzergâh üzerinde ilkbahar mevsiminden sonbahar 
mevsimine kadar yapacakları yolculuk nedeniyle, kış aylarında barındıkları yerleri terketmek zorunda kalmaktadır (Arayıc1, 2008).

Türkiye'de yaşayan Çingenelerin pek çoğu anadilleri olan "Romani" diliyle konuşmakta ve iletişim kurmaktadır. Özgür yaşamayı sevdikleri ve birisinin emri altında çalışmayı sevmedikleri için esnek, sürekli olmayan işleri yapmayı tercih etmektedirler. Yaptıkları işler genel olarak hamallık, seyyar satıclık, ayakkabı boyacılığı ve müzisyenliktir. Teknolojinin gelişmesiyle birlikte geleneksel uğraşları olan demircilik ve kalaycılı̆̆ı daha az yapmaktadırlar (Ünaldı, 2012).

Türkiye'de İslam inancına sahip Çingeneler, itikadi açıdan kendilerini Bektaşi-Alevi ve Sünni olmak üzere iki gruba ayırmaktadır. Özellikle göçer durumda olanların pek çoğu Bektaşi-Alevi Müslüman, yerleşik durumda olanların büyük çoğunluğu ise Sünni Müslüman olarak bilinmektedir (Ünaldı, 2012).

Türkiye bağlamında değerlendirildiğinde; Karadeniz Bölgesinde yaşayanlara Lom, Güneydoğu Anadolu Bölgesinde yaşayanlara Dom adı verilmektedir; bu gruplar hakkında yeterli bilgi bulunmamaktadır. Türkiye'de kamusal söylemde 'Roman' olarak tanımlanan ve batı bölgelerinde yaşayan Rom grupları en fazla bilinen Çingene grubunu oluşturmaktadır (Kolukırık, 2008).

Çingenelerin esnek ve mevsimsel işleri tercih ettikleri bilinmektedir. Aslında temel olarak kalıcı işlerden uzak durdukları söylenebilir. Çingenelerin sadece müzikleri ve bununla alâkalı işlerle tanınması aslında topluluk için bir problem oluşturmaktadır. Müzik yetenekleri sosyal ve tarihi şartlardan dolayı öne çıkmıştır. Aynı zamanda bir tür "pazarlama" aracıdır. Tekelleşme ve müşterek çalışma metotları Romanlar arasında son derece yaygın bir özellik olarak öne çıkmaktadır. Avrupa'ya vardıkları tarihten itibaren Romanlar, ticaretle ilgilenen sanatçlar ve şahıslar haline gelmiştir. Romanlar geleneksel olarak at satıcıları, bakıcıları ve bekçileri olarak görülmüştür. Tüm Roman ekonomisi serbest meslek, eski yeteneklerin idamesi ve yeni teknolojik ilerlemelere ayak uydurmak için yeni yeteneklerin geliştirilmesi şeklinde süregelmiştir (Kolukırık, 2005). 


\section{Çingenelere Yönelik Algılar}

Ön yargılar, sosyal etkileşimin çıktılarıdır. Sosyal etkileşim süreci içerisinde birey ve grupların birbirlerine bakış açısı veya kapalılığı ön yargıları üretmektedir. Çingene olmayanların, Çingenelere karşı tutumları günlük dilde kullanılan deyişlere girmiştir (Ünaldı, 2008). Bunlardan bazıları şöyledir:

- Çingene çalar, Kürt oynar!

- Bahçeye erik, kapıya Çingene bastırma!

- Yetmiş iki milletin buçuğu!

- Çingeneleşme!

- Çingene pembesi!

- Çingene borcu!

- Çingene kavgası!

Bu tür önyargilar Çingene olmayanlarla Çingenelerin normal ilişki kurmasına engel olmakta, Çingenelerin daha herhangi bir bağlantı kurulmadan ötelenmesine neden olmaktadır. Çingeneler hakkındaki bütün bu olumsuz yargılar onları yeterince tanımamaktan kaynaklanmaktadır (Ünaldı, 2008).

\section{Materyal ve Metot}

\section{Materyal}

Bu çalışmaya temel oluşturan ve mahallenin kültürel ekolojisini anlamamıza yardımcı olan ilk veriler üç yıllık süre içerisinde Göktaş Mahallesi'n ndeki gözlemler ve halkla yapılan görüşmeler ile toplanmıştır. Araştırmanın kapsamını oluşturmakta yararlanılan bu verilerin toplanması için gerçekleştirilen saha çalışmalarında katılımlı gözlem ve etnografik yöntem kullanılmıştır.

Daha önce bu benzer bir çalışmanın yapılmaması, mahallenin mesafeli ve beklentilerinin yüksek olması sebebiyle çok sayıda ziyaretin ve görüşmenin ardından, belirli bir güven ortamı oluştuktan sonra sohbet ortamında notlar tutulmuş, daha önce kültürel ekoloji yaklaşımını kullanan diğer bilim dallarındaki çalışmalarda geliştirilen anket formlarından yararlanılarak oluşturulan hane halkına yönelik anket formları köyün ileri gelenleri ile de tartışlarak son hali verilmiştir. Araştırmada toplanan verilerin kapsamı Şekil 1'de sunulmuştur. 


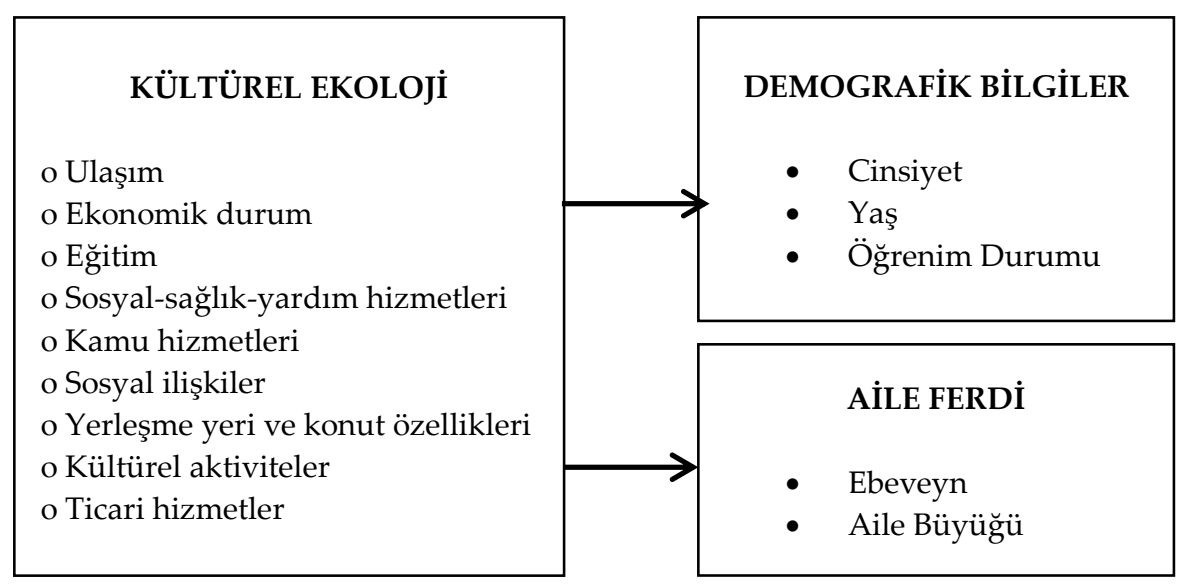

Şekil 1. Araştırma sorularının ana kapsamı

\section{Metot}

Araştırmanın evrenini, Isparta Eğirdir ilçesine bağlı Göktaş Mahallesi sakinleri oluşturmaktadır. Araştırma kapsamındaki anket çalışmasına, mahalledeki 138 haneden 118'ü katılmıştır. Hanehalkına yönelik olan anket formları 5'li likert (1: Kesinlikle katılmıyorum; 2: Kısmen katılmıorum; 3: Katılıyorum; 4: Kısmen katılıyorum; 5: Kesinlikle katılıyorum) ölçeğine göre düzenlenmiştir.

Çalışma kapsamında gözlem ve görüşmelerde etnografik yöntem benimsenmiştir. Etnografi, "insan topluluklarının ilişkilerini ve davranışlarını kendi ortamlarında gözleme, belgeleme ve yorumlama" olarak tanımlanmaktadır (Akturan, 2007).

Etnografik çalışmalar antropoloji, sosyal bilimler ve daha birçok alan tarafından kullanılmaktadır. Etnografik araştırmalarda esas olan, grup üyeleriyle doğrudan ilişki kurulmasıdır. Bu açıdan etnografik araştırmalar kalitatif saha araştırmalarıdır. Bu da bireylerin davranışının oluştuğu ve geliştiği sosyal altyapıya yönelik dikkat ve duyarlılık içeren bir araştırma tekniğidir (Akturan, 2007). Etnografik araştırmada tek bir olgu için anket, gözlem, kayıt gibi birden fazla yöntem kullanılabilmektedir.

Etnografik araştırmada araştırmacı incelenen kültürün, grubun bir parçasıdır ve bu kültür tarafından etkilenmektedir. Etnografik araştırmanın dört temel prensibi vardır (Akturan, 2007): 
1. Araştırmanın doğal ortamda yapılıyor olmasıdır. Başka bir deyişle etnografik araştırma, kişileri köylerinde, evlerinde, tarlalarında, sosyalleşme mekânlarında gözlemleyerek doğal ortamlarındaki davranışlarını anlamayı gerektirmektedir. Böylece kişiler gerçek dünyalarında gerçek tavır ve tutumlariyla tanımlanabilmektedir.

2. Araştırmacı, araştırma sürecinde dünyayı karşısındakinin gözünden görmeye çalışır. Bu varsayım, çalışmaya konu olan kişilerin sembolik dünyaları anlaşılmadan kişilerin sosyal davranışlarına yönelik bir betimleme geliştirilemeyeceği görüşüne dayanmaktadır. Bu varsayım doğrultusunda araştırmacı, kullanılan dili, jargonlarını, kelimelerin özel kullanımların bilmelidir.

3. Araştırmacının, kişilerin günlük yaşamlarının içinde yer alması ve olayları tecrübe etmesidir. Dolayısıyla araştırmacı gerçek zamanlı gelişen olaylara tanıklık ederek gerçek zamanlı bir öngörü geliştirme ve bu veriler ışığında sistematik analizler yapabilme imkânı bulmaktadır.

Araştırmacının kültürel ve sembolik anlamları, yerel kuralları, gelenek ve görenekleri bilmesi ve anlaması gerektiğidir.Böylece, problemler bizzat onları yaşayanların gözü ile görülmeye çalışılmaktadır.

Bu çalışmada, Eğirdir Gölü ve Göktaşlılar arasındaki etkileşim kültürel ekoloji yaklaşımıyla ele alınmıştır. Geçici/günlük işlerle geçimlerini sağlamaya alışık bir gelenekten gelen Göktaşlılar, Eğirdir Gölü'nün sağladığı fırsatlarla zamanla balık ve kerevit avcılığ 1 ile geçinir olmuş; ancak daha gölde ortaya çıkan ve "Kerevit" olarak anılan mantar hastalığı sonrası bu geçim kaynağı ortadan kalkmıştır. Çalışmada gölün ve göldeki bu değişikliklerin Göktaş halkın yaşamını nasıl etkilediği etnografik yöntemlerle araştırılmıştır.

\section{Bulgular ve Tartışma}

\section{Gözleme dayah bulgular}

Çalışmanın bu kısmı 2015 ila 2018 yılları arasındaki üç yıllık süreç içerisinde Göktaş Mahallesi'nde yapılan gözlemler ve görüşmelerden elde edilen bilgilerle oluşturulmuştur. Çalışma kapsamında gözlem ve görüşmelerde etnografik yöntem benimsenmiştir. Bu bölümde yer alan bilgiler, Göktaş Mahallesi'nin kültürel dokusunu daha iyi tanıma amacıyla toplanmıştır. Bu amaçla aşağıdaki konulara yönelik verilerle çalışılmıştır: 
- Yerleşim tarihçesi,

- Yerleşme ve konut şekilleri,

- Nüfus yapısı ve göç hareketleri,

- Aile yapisi,

- Önderlik,

- Mahallede yardımlaşma-işbirliği,

- Ekonomik yapı,

- Mülk durumu-mal varlıkları-sosyo ekonomik durum,

- Tarımsal üretim,

- Geçim kaynakları ve zaman içerisinde değişimi,

- Altyapi ve kamusal hizmetler,

- Sağlık hizmetleri,

- Mahallenin sorunları,

- Mahallede yaşayanların istek ve beklentileri,

- Yöresel olarak kullanılan kelimeler ve anlamları,

- Yakın köylerde yaşayanların Göktaş Mahalle'si hakkındaki görüşleri,

- Mahalledeki adetler

Bu konulardan bazıları önceden hazırlanmış sorular yöneltilerek yüz yüze görüşmeler şeklinde, bazıları ise gözlemler ve kayıtlardan elde edilen ek bilgilerle elde edilmiştir. Bu bölümün amacı, Göktaş Mahallesi'nin kültürel dokusunu ve ekoloji içerisinde durumunu anlamaktır. Görüşmelere mahalle halkı ile başlanmış, sonrasında görüşmelerde ortaya çıkan konulara açıllık getirmek için diğer görüşmeler gerçekleştirilmiştir. Diğer görüşmeler, Eğirdir Kaymakamlığı, Tarım ve Orman Bakanlığı Eğirdir İlçe Müdürlüğü, Su Ürünleri Araştırma Enstitüsü yetkilileriyle yapılmıştır. Ayrıca mahalleli hakkındaki genel düşünce ve yargıları derleyebilmek için de civardaki yerleşim yerlerinden kişiler ile görüşülmüştür.

\section{Göktaş Mahallesi hakkında genel bilgiler}

Mahalle, Isparta İli, Eğirdir İlçesine bağlı muhtarlık bir mahalledir. Eğirdir İlçesi'ne 14 km uzaklıkta 81.500 m² yüzölçümüne sahip olan Göktaş, Eğirdir Gölü etrafinda konumlanmıştır. Yolu, Eğirdir-Konya karayolu üzerinde 13 km'si asfalt ve 1 km'si ise stabilizedir. Mahallenin kuzeyi Eğirdir Gölü, gü- 
neyi Baybuğan Mahallesi, doğusunda Eğirdir Belediyesi'ne ait hayvanat bahçesi (Rüya Park), batısı ise Sorkuncak Köyü'ne ait elma bahçeleri ile çevrilidir. Göktaş Mahallesi 1999 yılına kadar köy statüsünde iken o yıl köyde yapılan oylama ile mahalle statüsüne alınmış, Ocak 2017'de yapılan ikinci bir oylama ile de 28 Mayıs 2018 tarihinde tekrar köy statüsüne geçmiştir. Bununla beraber bu statünün uygulamaya henüz yansımadığı söylenebilir. Bu araştırmanın saha çalışmaları, yerleşim birimi mahalle statüsünde iken gerçekleştirilmiş ve o nedenle makalede de "mahalle" tabirinin kullanımı benimsenmiştir.

Göktaş Mahallesi 138 haneden oluşmaktadır. Mahallede toplam 384 kişi yaşamaktadır. Nüfus, son on yıl içinde 495 ila 312 arasında değişmektedir (TÜİK, 2020). Bugün itibariyle, köyde kayıtlı 138 hane 'Abdallar' (113 hane) ve 'Elekçiler' (25 hane) olarak kendi içlerinde ikiye ayrılmıştır. Abdallar, İranHorasan'dan gelen grup; Elekçiler ise Aksu-Yakaavşar'dan gelen gruptur. Yaşayanların \%53,4'ü erkek ve \%46,6’sı kadındır.

\section{Toplumsal ve ekonomik yapı}

Göktaş'ın sosyo-ekonomisini belirleyen iki önemli faktör göl ve geleneksel yapılarıdır. Mahallenin kenarına konumlandı̆̆ı Eğirdir Gölü’nün gölün sunduğu kerevit ve balık avcılığı 1970 yılından 1985 yılına kadar mahallelinin geçim kaynağ1 olmuştur. Fakat günümüzde bu temel geçim kaynağ1 yok olmuştur. Su Ürünleri Araştırma Enstitüsünden edinilen bilgilere göre, o yıllar arasında kerevit ve balık avcılığına halkın aşırı yüklenmesi ve son olarak da ortaya çıkan bulaşıcı hastalık sebebiyle bitme noktasına gelmiştir. Yukarıda bahsedilen ve 'kerevit hastalığı' olarak adlandırılan bir mantar hastalığının Çivril'in Işıklı Köyü'nde gölde ortaya çıktığı ve orada avlanmada kullanılan alet ve ekipmanın Eğirdir çevresindeki avcılarca satın alınıp ve Eğirdir Gölü'ne salınmasından itibaren burada da görülmeye başladığı belirtilmektedir. Balık avcılığı da, kerevit hastalığı ve zamansız (küçük balıkların avlanması ve/veya üreme döneminde) avlanmaya bağlı olarak yok denecek kadar azalmıştır.

Eskiden mahallelinin hemen tamamının geçim kaynağı kerevit ve balık avcılığıyken şimdilerde bu oran çok düşmüş, hatta 2000'li yıllara kadar kerevit avcılığı tamamen durmuştur. Göldeki kerevit popülasyonu 2002-2006 y1lları arasında artmıştır fakat ekonomik anlamda mahalleye katkısı olmamıştır. 
Eskiden mahallede çoğu kişi kayıtlı avcı iken günümüzde yeterli gelir sağlanmadığı ve bürokratik işlemlerden dolayı kayıtlı avcılık yapanların sayısı çok azdır. Avcılık yaptığı bilinen onlarca kişiden sadece dördü bugün hâlâ belediyenin balıkçılık kooperatifine kayıtlıdır ve izinli avlanma yapmaktadır. Son beş yıldır göle yoğun miktarda balık bırakılmakta ve yasaklar sıkı bir şekilde takip edilmektedir. Bu gelişmelerin bir sonucu olarak, avcılı̆̆ın Eğirdir ve mahalle için tekrar geçim kaynağı olacağı tahmin edilmektedir.

Göl ve insanlar arasındaki etkileşimler geçim kaynakları ve hayat tarzlarına yansımaktadır. Ekolojik zenginlikler yönünden son derece hassas, yaşamsal ve ekonomik bakımdan çok önemli olan gölün, bilinçli/bilinçsiz müdahaleler sonucunda uğradığı değişim, mahallede yaşayanların yaşam biçimlerini derinden etkilemiştir. Gölde balıkçılı̆̆n yapılabildiği ve geçim kaynağının göl olduğu dönemlerde mahalleli çoğunlukla göl üzerinden gelir sağlarken gölün değişimi ile mahalledeki hemen hemen herkes göl dışından gelir sağlama yoluna gitmiştir. Ekilebilir ve kullanılabilir arazi olmadığı için halk, mahalle dışında iş arayışı içindedir. Erkekler kış aylarında Antalya'ya giderek otellerde garsonluk ve inşaat işçiliği gibi işlerde çalışmakta, yazın mahalleye dönerek, müzisyenlik, elma toplama, soğuk hava depolarında elma seçimi, balık işleme tesislerinde çeşitli işler, bahçe budama ve inşaat işçiliği gibi günübirlik işlerde çalışmaktadırlar. Kadınlar da eskiden kayıklarla gölden avc1lık yaparken şimdi müzisyenlik, elma toplama, soğuk hava depolarında elma seçimi, balık işleme tesislerinde ve ev temizliğine gitmek şeklinde aile ekonomisine katkıda bulunmaktadırlar.

Göktaş'ta müzik hem geçim kaynağı hem mahalle hayatının vazgeçilmez bir parçasıdır. Saha çalışmaları sırasında kapısı açık olan hemen her evde saz, org veya darbuka gibi müzik aletlerini çalan kişilere rastlanılmıştır. Erkek ve kadınlar düğünlerde çalgıcılık yapmaktadırlar. Erkekler ayrıca gazino ve müzikli restoranlarda da çalışmaktadır.

\section{Aile yapısı}

Mahallede yapılan görüşmeler ve saha çalışmalarında edinilen bilgilere göre çekirdek aile yapısı hâkimdir. Ankete katılanların çoğu evlidir. Ancak mahallede yaşayan kişilerin medeni durumla ilgili dile getirmek istedikleri bazı noktalar olmuştur. Örneğin, "çocuklarımızı nişanlıyoruz (kızların yaşı en fazla 17, erkekler ise askere gitmeden) fakat düğün masrafı olmasın diye 
kaçma olayları çok görülüyor" diyen aileler olmuştur. Kızın ailesine günün şartlarına göre belli bir miktar başlık parası verilmektedir. Aileler de başlık alabilmek için kaçma olayına biraz sıcak bakmaktadırlar. Kaçma/kaçırma ve küçük yaşta evlilik kadar boşanma oranı da çok yüksektir. Aile içindeki yetki dağılımının kime ait olduğuna dair soruya, görüşülen kişilerin \%54'ü annebaba, \%20'si baba, \%12'si anne ve \%14'ü de aile büyüklerinde (dede-nine) olduğunu ifade etmiştir. Geniş aileler için bakıldığında, aile büyüklerinin yetki ve otoritesinin ağırlığ $\% 14^{\prime}$ ten \%35'e çıkmaktadır (Şekil 2).

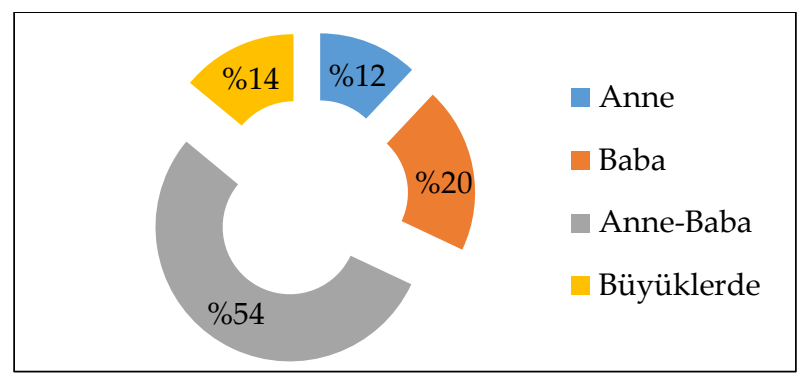

Şekil 2. Aile içinde kimin sözü geçer?

İş ve meslek dăğllımı: Ekilebilir ve kullanılabilir arazi olmadığı için halk, mahalle dışında iş arayışı içindedir. Erkekler kış aylarında Antalya'ya giderek otellerde garsonluk ve inşaat işçiliği gibi işlerde çalışmakta, yazın mahalleye dönerek, müzisyenlik, elma toplama, soğuk hava depolarında elma seçimi, balık işleme tesislerinde çeşitli işler, bahçe budama ve inşaat işçiliği gibi günübirlik işlerde çalışmaktadırlar (Şekil 3). Mahallede her iki cinsiyette de SSK ve Bağkur'dan emekli olanlar vardır. Bu kişilere sorulduğunda Eğirdir'de 1950-1996 yılları arasında kerevit ve balık işleyen işletmede (kendi deyimleriyle "fabrikada") çalışıp daha sonra eksik gelen günleri kendileri ödeyerek emekli oldukları öğrenilmiştir.

Mahalledeki başlıca sosyo ekonomik sorunlar, işsizlik göç, göç nedeniyle ailelerin parçalanması ve sağlık ocağının sürekli olmaması olarak belirlenmiştir.

Ana sosyal-kültürel sorunlar ise kahvehanenin olmaması, sosyal ve sportif tesislerin yokluğu, çocuklar ve kadınlar için özel bir faaliyetin olmaması, park eksikliği gibi nedenlerden kaynaklanmaktadır. 


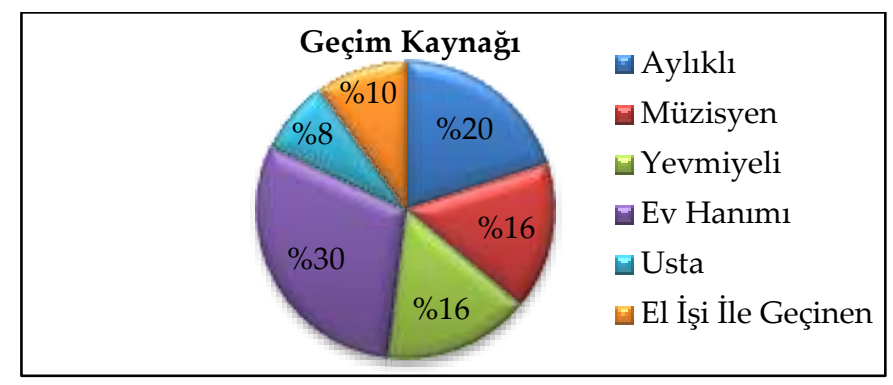

Şekil 3. Geçim kaynă̆ı

\section{Demografik Bilgiler}

Araştırmanın bu bölümüne katılan 118 kişinin 61'i kadın ve 57'si erkek; bu kişilerin 100'ü anne veya baba (ebeveyn) ve 18'i de aileyle birlikte yaşayan anneanne/babaanne veya dededir (aile büyügü̈). Görüşülen kişilere ait demografik veriler Tablo 1'de sunulmuştur.

Katılımcilar, en çok 31-40 yaş arasında (\%46,4) dağılmakta ve büyük bir çoğunluğunun eğitim düzeyleri ilkokul $(\% 78,8)$ seviyesindedir. Demografik veriler arasında en dikkat çekici özelik eğitim düzeyidir. Zira eğitim düzeyi tüm katılımcılarda ortaokul ve altıdır. Bu da Göktaş Mahallesinde genel olarak düşük bir eğitim düzeyi olduğunu göstermektedir.

Tablo 1. Görüşülen aile ferdine ait demografik bilgiler

\begin{tabular}{llll}
\hline & Nitelik & Frekans & $\mathbf{( \% )}$ \\
\hline \multirow{2}{*}{ Aile ferdi } & Ebeveyn & 100 & 84,7 \\
\cline { 2 - 4 } & Aile Büyüğ̈̈ & 18 & 15,3 \\
\hline \multirow{2}{*}{ Cinsiyet } & Kadın & 61 & 51,7 \\
\cline { 2 - 4 } & Erkek & 57 & 48,3 \\
\hline \multirow{2}{*}{ Yaş } & $20-30$ yaş arası & 35 & 29,4 \\
\cline { 2 - 4 } & 31-40 yaş arası & 55 & 46,4 \\
\cline { 2 - 4 } & 41-50 yaş arası & 17 & 14,3 \\
\hline \multirow{2}{*}{ Ĕgitim } & 51 ve üzeri & 11 & 9,0 \\
\hline
\end{tabular}




\section{Kültürel Ekoloji Yargılarna İlişkin Bulgular}

Ulaşım: Katılımcıların ulaşım ile ilgili sorulara verdikleri cevapların dağılımı Tablo 2' de verilmiştir. Ulaşımla ilgili verilen cevaplara göre, katılımcılar mahalleden şehir merkezine ulaşımın çok kolay olmadığını ve mahallenin şehirle ve şehrin önemli kesimleriyle bağlantısının kesik olduğunu düşünmektedir. Katılımcılar yerleşmede bir ayrılmış yol olmasının yaşanabilirliği azalttığını düşünmektedir. Katılımcıların çoğunluğu yerleşmedeki yürüyüş yollarının oldukça dar olduğunu ve mahalledeki yolların engelli insanlar için uygun olmadığını düşünmektedir.

Tablo 2. Ulaşım ile ilgili yargılar

\begin{tabular}{|c|c|c|c|c|c|c|c|c|}
\hline & & 1 & 2 & 3 & 4 & 5 & Ort. & Ss. \\
\hline \multirow{2}{*}{$\begin{array}{l}\text { Mahalleden şehir merkezine ulaşım çok } \\
\text { kolaydır. }\end{array}$} & $\mathbf{N}$ & 73 & 40 & - & 3 & 2 & \multirow{2}{*}{1,483} & \multirow{2}{*}{0,781} \\
\hline & $\%$ & 61,9 & 33,9 & - & 2,5 & 1,7 & & \\
\hline \multirow{2}{*}{$\begin{array}{l}\text { Mahallenin şehrin kalanıyla bağlantısı } \\
\text { kesiktir. }\end{array}$} & $\mathbf{N}$ & 5 & - & 11 & 49 & 53 & \multirow{2}{*}{4,229} & \multirow{2}{*}{0,937} \\
\hline & $\%$ & 4,2 & - & 9,3 & 41,5 & 44,9 & & \\
\hline \multirow{2}{*}{$\begin{array}{l}\text { Mahallenin şehrin önemli kesimleriyle } \\
\text { bağlantısı iyidir }\end{array}$} & $\mathbf{N}$ & 65 & 42 & 6 & 1 & 4 & \multirow{2}{*}{1,619} & \multirow{2}{*}{0,895} \\
\hline & $\%$ & 55,1 & 35,6 & 5,1 & 0,8 & 3,4 & & \\
\hline \multirow{2}{*}{$\begin{array}{l}\text { Yerleşmede bir ayrılmış yol olması yaşa- } \\
\text { nabilirliği azaltmaktadır. }\end{array}$} & $\mathbf{N}$ & 6 & 5 & 8 & 49 & 50 & \multirow{2}{*}{4,119} & \multirow{2}{*}{1,055} \\
\hline & $\%$ & 5,1 & 4,2 & 6,8 & 41,5 & 42,4 & & \\
\hline \multirow{2}{*}{$\begin{array}{l}\text { Yerleşmedeki yürüyüş yolları oldukça } \\
\text { dardır. }\end{array}$} & $\mathbf{N}$ & 3 & - & 1 & 56 & 58 & \multirow{2}{*}{4,407} & \multirow{2}{*}{0,753} \\
\hline & $\%$ & 2,5 & - & 0,8 & 47,5 & 49,2 & & \\
\hline \multirow{2}{*}{$\begin{array}{l}\text { Mahalledeki sokaklar hareketliliğe izin } \\
\text { vermektedir. }\end{array}$} & $\mathbf{N}$ & 4 & 7 & 8 & 46 & 53 & \multirow{2}{*}{4,161} & \multirow{2}{*}{1,020} \\
\hline & $\%$ & 3,4 & 5,9 & 6,8 & 39 & 44,9 & & \\
\hline \multirow{2}{*}{$\begin{array}{l}\text { Mahalledeki yollar engelli insanlar için } \\
\text { uygundur. }\end{array}$} & $\mathbf{N}$ & 63 & 52 & 3 & - & - & \multirow{2}{*}{1,492} & \multirow{2}{*}{0,550} \\
\hline & $\%$ & 53,4 & 44,1 & 2,5 & - & - & & \\
\hline \multirow{2}{*}{$\begin{array}{l}\text { Dışarıdan mahalleye gelen kişiler, ma- } \\
\text { halleye gelebilmek için çok kolay toplu } \\
\text { taşıma aracı bulabilirler. }\end{array}$} & $\mathbf{N}$ & 95 & 23 & - & - & - & \multirow[b]{2}{*}{1,195} & \multirow[b]{2}{*}{0,397} \\
\hline & $\%$ & 80,5 & 19,5 & - & - & - & & \\
\hline \multirow{2}{*}{$\begin{array}{l}\text { Mevcut otobüs hizmetleri daha sık olma- } \\
\text { lıdır. }\end{array}$} & $\mathbf{N}$ & - & - & 1 & 41 & 76 & \multirow{2}{*}{4,636} & \multirow{2}{*}{0,500} \\
\hline & $\%$ & - & - & 0,8 & 34,7 & 64,4 & & \\
\hline \multirow{2}{*}{ Otobüsler, çoğunlukla uygun değildir. } & $\mathbf{N}$ & - & - & 3 & 56 & 59 & \multirow{2}{*}{4,475} & \multirow{2}{*}{0,550} \\
\hline & $\%$ & - & - & 2,5 & 47,5 & 50 & & \\
\hline \multirow{2}{*}{ Ulaşımda çok zaman kaybediyorum. } & $\mathbf{N}$ & 1 & 4 & 3 & 37 & 73 & \multirow{2}{*}{4,500} & \multirow{2}{*}{0,781} \\
\hline & $\%$ & 0,8 & 3,4 & 2,5 & 31,4 & 61,9 & & \\
\hline
\end{tabular}

Ekonomi: Katılımcların ekonomi ile ilgili sorulara verdikleri cevapların dağılımı Tablo 3'te görülmektedir. Cevaplarda büyük çoğunluk mahallede iş imkânının olmadığını ve işsizlik oranının yüksek olduğunu, çalışanların gelirlerinin memnun edici düzeyde olmadığını belirtmiştir. Görüşülen kişiler, 
çalışanların sektörel dağılımlarının dengeli olmadığını; bununla birlikte çalışanlar arasında kadın sayısının yüksek olması nedeniyle cinsiyet dengesi açısindan durumun görece daha iyi olduğunu düşünmektedir.

Tablo 3. Ekonomi ile ilgili yargilar

\begin{tabular}{|c|c|c|c|c|c|c|c|c|}
\hline & & 1 & 2 & 3 & 4 & 5 & Ort. & Ss. \\
\hline \multirow{2}{*}{ Mahallede iş imkânı çoktur. } & $\mathbf{N}$ & 91 & - & 27 & - & - & \multirow{2}{*}{1,220} & \multirow{2}{*}{0,421} \\
\hline & $\%$ & 77,1 & - & 22,9 & - & - & & \\
\hline \multirow{2}{*}{ Mahallede işsizlik oranı yüksektir. } & $\mathbf{N}$ & - & - & 70 & - & 48 & \multirow{2}{*}{4,400} & \multirow{2}{*}{0,493} \\
\hline & $\%$ & - & - & 59,3 & - & 40,7 & & \\
\hline \multirow{2}{*}{$\begin{array}{l}\text { Çalışanların sektörel dağılımı } \\
\text { dengelidir. }\end{array}$} & $\mathbf{N}$ & 54 & - & 56 & 8 & - & \multirow{2}{*}{1,610} & \multirow{2}{*}{0,613} \\
\hline & $\%$ & 45,8 & - & 47,5 & 6,8 & - & & \\
\hline \multirow{2}{*}{ Mahallede kadın çalışan çoktur. } & $\mathbf{N}$ & - & 10 & 51 & 57 & - & \multirow{2}{*}{4,398} & \multirow{2}{*}{0,642} \\
\hline & $\%$ & - & 8,5 & 43,2 & 48,3 & - & & \\
\hline \multirow{2}{*}{ Gelirim beni memnun ediyor. } & $\mathbf{N}$ & 71 & - & 42 & 1 & 4 & \multirow{2}{*}{1,474} & \multirow{2}{*}{0,688} \\
\hline & $\%$ & 60,2 & - & 35,6 & 8 & 3,4 & & \\
\hline
\end{tabular}

Eğitim: Katılımcıların eğitim ile ilgili sorulara verdikleri cevapların dağılımı Tablo 4'te görülmektedir. Eğitim ile ilgili verilen cevaplarda, katılımcıların büyük çoğunluğu mahalledeki eğitimi yeterli görmemekte ve taşımalı eğitim sisteminin iyi olmadığını, taşımalı sistemde gittikleri okulda çocuklarına iyi davranılmadığını düşünmektedirler. Ayrıca, mahallelerinde ortaöğretim kurumu olması gerektiğini düşünmektedir. Eğitimin gerekli olduğunu ve okumadıkları için pişman olduklarını belirtenlerin oranı yüksektir. Ayrıca büyük çoğunluk iyi bir meslek sahibi olmanın en büyük hayalleri olduğunu belirtmişlerdir.

Tablo 4. Eğitim ile ilgili yargılar

\begin{tabular}{|c|c|c|c|c|c|c|c|c|}
\hline & & 1 & 2 & 3 & 4 & 5 & Ort. & Ss. \\
\hline \multirow{2}{*}{ Mahallede eğitim hizmetleri iyidir. } & $\mathbf{N}$ & 67 & & 48 & 3 & & \multirow{2}{*}{1,458} & \multirow{2}{*}{0,549} \\
\hline & $\%$ & 56,8 & & 40,7 & 2,5 & & & \\
\hline \multirow{2}{*}{ Eğitimde taşımalı sistem çok iyidir. } & $\mathbf{N}$ & 47 & 63 & 3 & 2 & 3 & \multirow{2}{*}{1,737} & \multirow{2}{*}{0,810} \\
\hline & $\%$ & 39,8 & 53,4 & 2,5 & 1,7 & 2,5 & & \\
\hline \multirow{2}{*}{ Mahallede ortaöğretim kurumu olmalı. } & $\mathbf{N}$ & & 1 & 1 & 44 & 72 & \multirow{2}{*}{4,585} & \multirow{2}{*}{0,559} \\
\hline & $\%$ & & 8 & 8 & 37,3 & 61,0 & & \\
\hline \multirow{2}{*}{$\begin{array}{l}\text { Taşımalı sistemde gittikleri okulda ço- } \\
\text { cuklarımıza iyi davranılmaktadır }\end{array}$} & $\mathbf{N}$ & 56 & 54 & 4 & 4 & & \multirow{2}{*}{1,627} & \multirow{2}{*}{0,713} \\
\hline & $\%$ & 47,5 & 45,8 & 3,4 & 3,4 & & & \\
\hline \multirow{2}{*}{ Eğitim gereklidir. } & $\mathbf{N}$ & & 2 & 1 & 30 & 85 & \multirow{2}{*}{4,678} & \multirow{2}{*}{0,582} \\
\hline & $\%$ & & 1,7 & 8 & 25,4 & 72,0 & & \\
\hline \multirow{2}{*}{ Okumadığım için pişmanım. } & $\mathbf{N}$ & & & 2 & 52 & 64 & \multirow{2}{*}{4,525} & \multirow{2}{*}{0,534} \\
\hline & $\%$ & & & 1,7 & 44,1 & 54,2 & & \\
\hline \multirow{2}{*}{$\begin{array}{l}\text { İyi bir meslek sahibi olmak en büyük ha- } \\
\text { yalimdi. }\end{array}$} & $\mathbf{N}$ & 1 & 1 & 2 & 35 & 79 & \multirow{2}{*}{4,610} & \multirow{2}{*}{0,654} \\
\hline & $\%$ & 8 & 8 & 1,7 & 29,7 & 66,9 & & \\
\hline
\end{tabular}


Sosyal ve sağlık yardımı: Katılımcıların sosyal ve sağlık yardım ile ilgili sorulara verdikleri cevapların dağılımı Tablo 5'te görülmektedir. Katılımcılar, yardımlarla ilgili sorulara verdikleri cevaplarda, katılımciların tamamı mahallede kolay erişilebilen bir sağlık ocağı olmadığını belirtmişlerdir. Ayrıca, yaşlı yardımlarının yeterli olmadığını, yaşlılar için bir merkezin bulunmadığını ve mahallenin sağlanan sosyal hizmetler bakımından zayıf olduğunu düşünenlerin oranı da yüksektir.

Tablo 5. Sosyal ve sağhk yardımlan ile ilgili yargılar

\begin{tabular}{|c|c|c|c|c|c|c|c|c|}
\hline & & 1 & 2 & 3 & 4 & 5 & Ort. & Ss. \\
\hline \multirow{2}{*}{$\begin{array}{l}\text { Mahalleden kolayca erişilebilen bir } \\
\text { sağlık ocağı bulunmaktadır. }\end{array}$} & $\mathbf{N}$ & 118 & & & & & \multirow{2}{*}{1,000} & \multirow{2}{*}{1,000} \\
\hline & $\%$ & 100,0 & & & & & & \\
\hline \multirow{2}{*}{$\begin{array}{l}\text { Yaşlılara yardım hizmetleri yerleş- } \\
\text { mede eksik kalıyor. }\end{array}$} & $\mathbf{N}$ & 4 & & 2 & 56 & 56 & \multirow{2}{*}{4,355} & \multirow{2}{*}{0,821} \\
\hline & $\%$ & 3,4 & & 1,7 & 47,5 & 47,5 & & \\
\hline \multirow{2}{*}{$\begin{array}{l}\text { Yerleşme sosyal hizmetlerle iyi dona- } \\
\text { tılmıştır. }\end{array}$} & $\mathbf{N}$ & & 64 & 51 & 2 & 1 & \multirow{2}{*}{1,500} & \multirow{2}{*}{0,623} \\
\hline & $\%$ & & 54,2 & 43,2 & 1,7 & 8 & & \\
\hline \multirow{2}{*}{$\begin{array}{l}\text { Yerleşmede yaşlılar için fonksiyonları } \\
\text { iyi olan bir merkez bulunmaktadır. }\end{array}$} & $\mathbf{N}$ & 67 & 49 & 2 & & & \multirow{2}{*}{1,466} & \multirow{2}{*}{0,594} \\
\hline & $\%$ & 56,8 & 41,5 & 1,7 & & & & \\
\hline
\end{tabular}

Kamu hizmetleri: Katılımcların kamu hizmetleri ile ilgili sorulara verdikleri cevapların dağılımı Tablo 6'da görülmektedir. Katılımclar, sokaklara yeterince bakılmadığını; çevrede çöp olduğunu, sokak ve kaldırımların yeterince temiz olmadığını, çöp toplama hizmetlerinin yeterli olmadığını, çöplerin ayrılması ve geri dönüştürülmesi konusunda iyi bir donanıma sahip olunmad1ğını düşünmektedir. Katılımcılar mahallede terkedilmiş alanların az olduğunu, buna rağmen sokak aydınlatmalarının yeterli olmadığını; insanların buluşabilecekleri bahçe/park olmadığını, dinlenmek ve yürümek için yeşil boş alanların yetersiz olduğunu ve yeşil alanların iyi durumda olmadığını; yeşil alanların kötü insanlar tarafından kullanıldığı için tehlikeli olduğunu belirtmişlerdir. Ayrıca, kurumsal hizmetlerden yeterince faydalanmadıkların, alt yapı hizmetlerinin yeterli olmadığını, mahallede yer alan derenin ıslah edilmesi gerektiğini düşünmektedirler (Tablo 6).

Sosyal ilişkiler: Katılımcıların sosyal ilişkilerle ilgili sorulara verdikleri cevapların dağılımı Tablo 7'de görülmektedir. Verilen cevaplara göre, mahalledeki insanların genellikle çok candan olduklarını, fakat insanların çok sosyal 
olmadıklarını düşünenlerin oranı yüksektir. Mahalledeki komşular çoğunlukla çevrelerinde tanındıklarını, bütün insanların kendisinden çok başkalarını düşündüğünü ve mahallede yaşlı insan sayısının fazla olduğunu belirtmişlerdir. Ayrıca görüşülen kişilerin çoğunluğu gençlerin birçoğunun yanlış yolda olduğunu düşünmektedir (Tablo 7).

Tablo 6. Kamu hizmetleri ile ilgili yargılar

\begin{tabular}{|c|c|c|c|c|c|c|c|c|}
\hline & & 1 & 2 & 3 & 4 & 5 & Ort. & Ss. \\
\hline \multirow[t]{2}{*}{ Sokaklara yeterince bakılmamaktadır. } & $\mathbf{N}$ & 1 & & 3 & 79 & 35 & \multirow[t]{2}{*}{4,245} & \multirow[t]{2}{*}{0,583} \\
\hline & $\%$ & 8 & & 2,5 & 66,9 & 29,7 & & \\
\hline \multirow{2}{*}{$\begin{array}{l}\text { Mahallede pek çok terkedilmiş alan var- } \\
\text { dir. }\end{array}$} & $\mathbf{N}$ & 58 & 44 & 7 & 7 & 2 & \multirow[t]{2}{*}{1,737} & \multirow[t]{2}{*}{0,937} \\
\hline & $\%$ & 49,2 & 37,3 & 5,9 & 5,9 & 1,7 & & \\
\hline \multirow[t]{2}{*}{ Çoğunlukla çevrede çöp vardır. } & $\mathbf{N}$ & 4 & 17 & 2 & 54 & 41 & \multirow[t]{2}{*}{3,940} & \multirow[t]{2}{*}{1,119} \\
\hline & $\%$ & 3,4 & 14,4 & 1,7 & 45,8 & 34,7 & & \\
\hline \multirow{2}{*}{$\begin{array}{l}\text { Bu yerleşme toplanan çöpün geri dönü- } \\
\text { şümü ve ayrılmasında iyi donanımlıdır. }\end{array}$} & $\mathbf{N}$ & 69 & 40 & & 7 & 2 & \multirow[t]{2}{*}{1,584} & \multirow[t]{2}{*}{0,899} \\
\hline & $\%$ & 58,5 & 33,9 & & 5,9 & 1,7 & & \\
\hline \multirow[t]{2}{*}{ Çöp toplama hizmetleri yeterlidir. } & $\mathbf{N}$ & 68 & 39 & 5 & 5 & 1 & \multirow[t]{2}{*}{1,5760} & \multirow[t]{2}{*}{0,831} \\
\hline & $\%$ & 57,6 & 33,1 & 4,2 & 4,2 & 8 & & \\
\hline \multirow{2}{*}{$\begin{array}{l}\text { Sokak aydınlatması çoğunlukla yetersiz- } \\
\text { dir. }\end{array}$} & $\mathbf{N}$ & 3 & 10 & 3 & 49 & 53 & \multirow[t]{2}{*}{4,178} & \multirow[t]{2}{*}{1,009} \\
\hline & $\%$ & 2,5 & 8,5 & 2,5 & 41,5 & 44,9 & & \\
\hline \multirow{2}{*}{$\begin{array}{l}\text { Mahallenin sokakları ve kaldırımları } \\
\text { yeterince temizdir. }\end{array}$} & $\mathbf{N}$ & 57 & 55 & 1 & 3 & 2 & \multirow[t]{2}{*}{1,627} & \multirow[t]{2}{*}{0,782} \\
\hline & $\%$ & 48,3 & 46,6 & 8 & 2,5 & 1,7 & & \\
\hline \multirow{2}{*}{$\begin{array}{l}\text { Bir parka gitmek, şehrin başka } \\
\text { kısımlarına gitmek demektir. }\end{array}$} & $\mathbf{N}$ & 1 & & 4 & 62 & 51 & \multirow[t]{2}{*}{4,372} & \multirow[t]{2}{*}{0,837} \\
\hline & $\%$ & 8 & & 3,4 & 52,5 & 43,2 & & \\
\hline \multirow{2}{*}{$\begin{array}{l}\text { İnsanların buluşabileceği en } \\
\text { azından bahçe/park vardır. }\end{array}$} & $\mathbf{N}$ & 76 & 42 & & & & \multirow[t]{2}{*}{1,355} & 0,480 \\
\hline & $\%$ & 64,4 & 35,6 & & & & & \\
\hline Mahallede, dinlenmek ve yürümek & $\mathbf{N}$ & 56 & 62 & & & & 1,525 & 0,501 \\
\hline için yeşil boşluklar vardır. & $\%$ & 47,5 & 52,5 & & & & & \\
\hline Mahallede yeşil alanlar iyi durumdadır. & $\mathbf{N}$ & 54 & 45 & 2 & 13 & 4 & 1,881 & 1,102 \\
\hline & $\%$ & 45,8 & 38,1 & 1,7 & 11,0 & 3,4 & & \\
\hline Mahallenin yeşil alanları kötü insanlar & $\mathbf{N}$ & 5 & 13 & 2 & 65 & 33 & 3,915 & 1,058 \\
\hline tarafından kullanıldığı için tehlikelidir. & $\%$ & 4,2 & 11,0 & 1,7 & 55,1 & 28,0 & & \\
\hline Mahallede pek çok işçi sınıfı sakini & $\mathbf{N}$ & 1 & 1 & 1 & 64 & 51 & 4,381 & 0,639 \\
\hline vardır. & $\%$ & 8 & 8 & 8 & 54,2 & 43,2 & & \\
\hline Bu mahalledeki insanlar huzur, mutlu- & $\mathbf{N}$ & 5 & 4 & 6 & 63 & 40 & 4,093 & 0,951 \\
\hline luk ararlar. & $\%$ & 4,2 & 3,4 & 5,1 & 53,4 & 33,9 & & \\
\hline Mahalleden kolayca erişilebilen bir sağ- & $\mathbf{N}$ & 1 & 12 & 1 & 59 & 45 & 140 & 097 \\
\hline lık ocağı bulunmaktadır & $\%$ &, 8 & 10,2 & 8 & 50,0 & 38,1 & 4,144 & 827 \\
\hline Yaşlılara yardım hizmetleri yerleşmede & $\mathbf{N}$ & 77 & 41 & & & & 1347 & 0478 \\
\hline eksik kalıyor & $\%$ & 65,3 & 34,7 & & & & 1,347 & 0,478 \\
\hline Yerleşme sosyal hizmetlerle iyi donatıl- & $\mathbf{N}$ & & 1 & & 42 & 75 & 4618 & 0537 \\
\hline miştır & $\%$ & & 8 & & 35,6 & 63,6 & 4,618 & 0,537 \\
\hline Yerleşmede yaşlılar için fonksiyonları & $\mathbf{N}$ & 55 & 53 & 3 & 2 & 5 & $7 ? 0$ & 032 \\
\hline iyi olan bir merkez bulunmaktadır & $\%$ & 46,6 & 44,9 & 2,5 & 1,7 & 4,2 & 1,720 & 0,932 \\
\hline
\end{tabular}


Tablo 7. Sosyal ilişkiler ile ilgili yargılar

\begin{tabular}{|c|c|c|c|c|c|c|c|c|}
\hline & & 1 & 2 & 3 & 4 & 5 & Ort. & Ss. \\
\hline \multirow{2}{*}{$\begin{array}{l}\text { Bu mahalledeki insanlar genellikle } \\
\text { çok candandır. }\end{array}$} & $\mathbf{N}$ & 3 & 8 & 6 & 64 & 37 & \multirow{2}{*}{4,050} & \multirow{2}{*}{0,932} \\
\hline & $\%$ & 2,5 & 6,8 & 5,1 & 54,2 & 31,4 & & \\
\hline \multirow{2}{*}{$\begin{array}{l}\text { Bu mahalledeki insanlar genellikle } \\
\text { çok sosyal değildirler. }\end{array}$} & $\mathbf{N}$ & 5 & 26 & 9 & 45 & 33 & \multirow{2}{*}{3,635} & \multirow{2}{*}{1,224} \\
\hline & $\%$ & 4,2 & 22,0 & 7,6 & 38,1 & 28,0 & & \\
\hline \multirow{2}{*}{$\begin{array}{l}\text { Mahalledeki komşular çoğunlukla } \\
\text { Tanınır. }\end{array}$} & $\mathbf{N}$ & & & & 42 & 76 & \multirow{2}{*}{4,644} & \multirow{2}{*}{0,480} \\
\hline & $\%$ & & & & 35,6 & 64,4 & & \\
\hline \multirow{2}{*}{$\begin{array}{l}\text { Mahalledeki bütün insanlar kendilerini } \\
\text { düş̧ünürler ve diğerleriyle çok az } \\
\text { İlgilenirler. }\end{array}$} & $\mathbf{N}$ & 53 & 41 & 2 & 18 & 4 & \multirow[b]{2}{*}{1,974} & \multirow[b]{2}{*}{1,180} \\
\hline & $\%$ & 44,9 & 34,7 & 1,7 & 15,3 & 3,4 & & \\
\hline \multirow{2}{*}{ Mahallede pek çok yaşlı vardır. } & $\mathbf{N}$ & 3 & 6 & 8 & 64 & 37 & \multirow{2}{*}{4,067} & \multirow{2}{*}{0,903} \\
\hline & $\%$ & 2,5 & 5,1 & 6,8 & 54,2 & 31,4 & & \\
\hline \multirow{2}{*}{$\begin{array}{l}\text { Mahallede pek çok yanlış yolda } \\
\text { genç insan vardır. }\end{array}$} & $\mathbf{N}$ & 2 & 9 & 9 & 52 & 46 & \multirow{2}{*}{4,110} & \multirow{2}{*}{0,958} \\
\hline & $\%$ & 1,7 & 7,6 & 7,6 & 44,1 & 39,0 & & \\
\hline
\end{tabular}

Yerleşime bağglılık: Katılımcıların yerleşime bağllık ile ilgili sorulara verdikleri cevapların dağılımı Tablo 8' de görülmektedir. Büyük çoğunluk mahallenin yaşamak için ideal bir yerleşme yeri olduğunu düşünmekte ve "bu mahalle benim bir parçamdır" diyebilmektedir. Mahallede duygusal yönden bağlı oldukları yerler olduğunu ve mahalleden ayrılmanın zor olacağını, bunun için de mahalleden ayrılmaya sıcak bakmadıklarını belirtmektedirler. Fakat gençlerin büyük bir kısmının mahalleden kaçmaya meyilli olduklarını belirtmişlerdir. Mahalledeki ailelerin çoğunluğu çekirdek aile olmakla birlikte geniş aile oranının yüksek olduğunu düşününenlerin oranı da yüksektir. Mahallelilere göre mahallede sakin bir yaşam sürülmektedir (Tablo 8).

Kültürel aktiviteler: Katılımcların kültürel aktiviteler ile ilgili sorulara verdikleri cevapların dağılımı Tablo 9'da görülmektedir. Katılımcılar, mahalledeki kültürel girişimlerin az olduğunu ve boş zamanlarını geçirebilecekleri bir yerin bulunmadığını belirtmektedirler. Mahallede herhangi bir toplanma mekânının bulunmadığını ve bu tür bir mekânın olması halinde genç insanların sokaklardan ayrılıp bu mekânlarda toplanmasının yararlı olacağını düşünmektedirler. Çoğunluk, cep telefonunun ve televizyonun çok faydalı bir iletişim aracı olduğunu düşünmektedirler (Tablo 9). 
Tablo 8. Yerleşime bağhlık ile ilgili yargılar

\begin{tabular}{|c|c|c|c|c|c|c|c|c|}
\hline & & 1 & 2 & 3 & 4 & 5 & Ort. & Ss. \\
\hline \multirow{2}{*}{ Yaşamak için ideal yerleşmedir. } & $\mathbf{N}$ & & 1 & 2 & 53 & 62 & \multirow{2}{*}{4,492} & \multirow{2}{*}{0,581} \\
\hline & $\%$ & & 8 & 1,7 & 44,9 & 52,5 & & \\
\hline \multirow{2}{*}{ Bu mahalle benim bir parçamdır. } & $\mathbf{N}$ & & & 7 & 59 & 52 & \multirow{2}{*}{4,381} & \multirow{2}{*}{0,598} \\
\hline & $\%$ & & & 5,9 & 50,0 & 44,1 & & \\
\hline \multirow{2}{*}{$\begin{array}{l}\text { Mahallede duygusal yönden bağlı oldu- } \\
\text { ğum yerler vardır. }\end{array}$} & $\mathbf{N}$ & 2 & 3 & 3 & 64 & 46 & \multirow{2}{*}{4,263} & \multirow{2}{*}{0,778} \\
\hline & $\%$ & 1,7 & 2,5 & 2,5 & 54,2 & 39,0 & & \\
\hline \multirow{2}{*}{$\begin{array}{l}\text { Bu mahalleden ayrılmak benim için çok } \\
\text { zor olacaktır. }\end{array}$} & $\mathbf{N}$ & & & 10 & 39 & 69 & \multirow{2}{*}{4,500} & \multirow{2}{*}{0,650} \\
\hline & $\%$ & & & 8,5 & 33,1 & 58,5 & & \\
\hline \multirow{2}{*}{ Bu mahalleden ayrılmaya gönüllüyüm. } & $\mathbf{N}$ & 63 & 55 & & & & \multirow{2}{*}{1,466} & \multirow{2}{*}{0,501} \\
\hline & $\%$ & 53,4 & 46,6 & & & & & \\
\hline \multirow{2}{*}{$\begin{array}{l}\text { Başka bir yer için bu mahalleden ayrıl- } \\
\text { maya gönüllü değilim. }\end{array}$} & $\mathbf{N}$ & & & & 57 & 60 & \multirow{2}{*}{4,513} & \multirow{2}{*}{0,502} \\
\hline & $\%$ & & & & 48,3 & 50,8 & & \\
\hline \multirow{2}{*}{$\begin{array}{l}\text { Evlerimizin yapımında kullandığımız } \\
\text { malzemeler günün koşullarına uygun- } \\
\text { dur. }\end{array}$} & $\mathbf{N}$ & & & & 72 & 46 & \multirow[b]{2}{*}{4,390} & \multirow[b]{2}{*}{0,490} \\
\hline & $\%$ & & & & 61,0 & 39,0 & & \\
\hline \multirow{2}{*}{ Bu mahallede çok az şey yapılabilir. } & $\mathbf{N}$ & & & 4 & 70 & 44 & \multirow{2}{*}{4,339} & \multirow{2}{*}{0,543} \\
\hline & $\%$ & & & 3,4 & 59,3 & 37,3 & & \\
\hline \multirow{2}{*}{$\begin{array}{l}\text { Genç insanlar bu mahalleden kaçmaya } \\
\text { meyillidir. }\end{array}$} & $\mathbf{N}$ & & 18 & 11 & 48 & 41 & \multirow{2}{*}{3,949} & \multirow{2}{*}{1,028} \\
\hline & $\%$ & & 15,3 & 9,3 & 40,7 & 34,7 & & \\
\hline \multirow{2}{*}{ Bu mahalle hareketlilikle doludur. } & $\mathbf{N}$ & 46 & 45 & 2 & 15 & 10 & \multirow{2}{*}{2,136} & \multirow{2}{*}{1,294} \\
\hline & $\%$ & 39,0 & 38,1 & 1,7 & 12,7 & 8,5 & & \\
\hline \multirow{2}{*}{ Mahallede sakin bir yasam ritmi vardır. } & $\mathbf{N}$ & 2 & 6 & 3 & 48 & 59 & 4202 & 0006 \\
\hline & $\%$ & 1,7 & 5,1 & 2,5 & 40,7 & 50,0 & 4,322 & 0,886 \\
\hline Mahallemizde aileler çekirdek ailedir & $\mathbf{N}$ & 3 & & & 53 & 62 & 500 & 0.551 \\
\hline (anne-baba ve çocuklar). & $\%$ & 2,5 & & & 44,9 & 52,5 & 4,500 & 0,551 \\
\hline Mahallemi & $\mathbf{N}$ & 2 & 26 & & 38 & 52 & 3949 & 1218 \\
\hline Mahallemizde & $\%$ & 1,7 & 22,0 & & 32,2 & 44,1 & 3,949 & 1,218 \\
\hline
\end{tabular}

Tablo 9. Kültürel aktiviteler ile ilgili yargılar

\begin{tabular}{|c|c|c|c|c|c|c|c|c|}
\hline & & 1 & 2 & 3 & 4 & 5 & Ort. & Ss. \\
\hline \multirow{2}{*}{$\begin{array}{l}\text { Mahalledeki kültürel girişimler çok } \\
\text { azdır. }\end{array}$} & $\mathbf{N}$ & & & 4 & 55 & 59 & \multirow{2}{*}{4,466} & \multirow{2}{*}{0,565} \\
\hline & $\%$ & & & 3,4 & 46,6 & 50,0 & & \\
\hline \multirow{2}{*}{$\begin{array}{l}\text { Bir toplanma mekânının olması yerleş- } \\
\text { medeki genç insanları sokaklardan top- } \\
\text { lar. }\end{array}$} & $\mathbf{N}$ & & & 5 & 51 & 62 & \multirow[b]{2}{*}{4,483} & \multirow[b]{2}{*}{0,581} \\
\hline & $\%$ & & & 4,2 & 43,2 & 52,5 & & \\
\hline \multirow{2}{*}{$\begin{array}{l}\text { Toplanma mekânlarının eksikliği bu } \\
\text { yerleşmede genç insanların boş zaman- } \\
\text { larını geçirmelerine izin vermemektedir. }\end{array}$} & $\mathbf{N}$ & & & 4 & 65 & 49 & \multirow[b]{2}{*}{4,381} & \multirow[b]{2}{*}{0,554} \\
\hline & $\%$ & & & 3,4 & 55,1 & 41,5 & & \\
\hline \multirow{2}{*}{$\begin{array}{l}\text { Mahallede, her zaman boş zamanlarını } \\
\text { geçirebileceğin bir yer bulursun. }\end{array}$} & $\mathbf{N}$ & 48 & 67 & 3 & & & \multirow{2}{*}{1,619} & \multirow{2}{*}{0,538} \\
\hline & $\%$ & 40,7 & 56,8 & 2,5 & & & & \\
\hline \multirow{2}{*}{$\begin{array}{l}\text { Televizyon çok faydalı bir iletişim aracı- } \\
\text { dır. }\end{array}$} & $\mathbf{N}$ & 3 & 9 & 5 & 64 & 36 & \multirow{2}{*}{4,034} & \multirow{2}{*}{0,946} \\
\hline & $\%$ & 2,5 & 7,6 & 4,2 & 54,2 & 30,5 & & \\
\hline \multirow{2}{*}{$\begin{array}{l}\text { Cep telefonu çok faydalı bir iletişim ara- } \\
\text { cıdır. }\end{array}$} & $\mathbf{N}$ & & & & 54 & 64 & \multirow{2}{*}{4,542} & \multirow{2}{*}{0,500} \\
\hline & $\%$ & & & & 45,8 & 54,2 & & \\
\hline
\end{tabular}


Ticari hizmetler: Katılımclların ticari hizmetler ile ilgili sorulara verdikleri cevapların dağılımı Tablo 10'da görülmektedir. Bu başlıktaki sorulara verilen cevaplarda, mahallenin yerel bir pazara yakın olmadığını, mahalleye ara sıra sebze meyve satan satıcıların geldiğini, bu satıcıların satış fiyatlarının normal piyasa değerinden fazla olmadığını belirtmişlerdir. Katılımcıların büyük çoğunluğu para harcayabilecekleri merkezlerin olmadığını düşünmektedirler.

Tablo 10. Ticari hizmetler ile ilgili yargılar

\begin{tabular}{|c|c|c|c|c|c|c|c|c|}
\hline & & 1 & 2 & 3 & 4 & 5 & Ort. & Ss. \\
\hline \multirow{2}{*}{ Mahalle yerel bir pazara yakındır. } & $\mathbf{N}$ & 72 & 45 & 1 & & & \multirow{2}{*}{1,551} & \multirow{2}{*}{1,870} \\
\hline & $\%$ & 61,0 & 38,1 & 8 & & & & \\
\hline \multirow{2}{*}{$\begin{array}{l}\text { Mahallemize ara sıra sebze meyve satan } \\
\text { satıcilar gelmektedir. }\end{array}$} & $\mathbf{N}$ & & & & 81 & 37 & \multirow{2}{*}{4,314} & \multirow{2}{*}{0,466} \\
\hline & $\%$ & & & & 68,6 & 31,4 & & \\
\hline \multirow{2}{*}{$\begin{array}{l}\text { Gelen satıcılar normal piyasa değerin- } \\
\text { den fazla fiyata satış yapmaktadırlar. }\end{array}$} & $\mathbf{N}$ & 66 & 41 & 8 & 3 & & \multirow{2}{*}{1,559} & \multirow{2}{*}{0,734} \\
\hline & $\%$ & 55,9 & 34,7 & 6,8 & 2,5 & & & \\
\hline \multirow{2}{*}{$\begin{array}{l}\text { Param var ama ihtiyaçlarımı satın alabi- } \\
\text { leceğim merkezler yok. }\end{array}$} & $\mathbf{N}$ & 7 & 35 & 3 & 41 & 32 & \multirow{2}{*}{3,475} & \multirow{2}{*}{1,325} \\
\hline & $\%$ & 5,9 & 29,7 & 2,5 & 34,7 & 27,1 & & \\
\hline
\end{tabular}

\section{Sonuç ve Öneriler}

Göktaş Mahallesi, yerleşim yeri olarak gölün kenarında olması ve peyzajı nedeniyle avantajlı, kırsal alan olmasına rağmen ekilebilir arazisinin olmaması nedeniyle dezavantajlı durumdadır. Buna rağmen Göktaş Mahallesi sakinlerinin geleneksel olarak tarım yapan bir kültürden gelmemekte oluşu nedeniyle bu durum kendileri için ciddi bir dezavantaj olarak tanımlanmamakta ancak kırsal alanların geleneksel olarak tarım ile geçindiği bir bölge olması nedeniyle hizmet sağlayıcıların kalıplaşmış önerilerinin dışına çıkılamaması nedeniyle bir sorun teşkil etmektedir. Mahalle sakinleri çok farklı bir kültürden ve alışkanlıklardan gelmekle birlikte kültürel ekolojiye uyum sağlamış, geçim kaynakları bu yönde belirlenmiştir. Eğirdir Gölü'nden kerevit ve balık avcllı̆̆ ile yakınlardaki balık işleme tesislerinde çalışarak geçimlerini sağlarken aşırı ve zamansız avlanma ile hastalık nedeniyle ortaya çıkan sektörel gerileme ile bu işlerini büyük ölçüde kaybetmişlerdir. Burada ortaya çıkan gelir kaybını kapatmak için tekrar müzisyenliğe ve yevmiyeli işlere yönelmişler, bu da köy dışına doğru dönemsel hareketliliklere yol açmıştır. Ancak araştırma sonuçları, mahalle sakinlerinin Göktaş'ta yaşamaya devam etmek istedikleri yönündedir. Göktaş'ın bölgedeki diğer kırsal alanlardan farklı olarak 
en büyük sorunu ve zayıf yanının, civardaki kötü şöhreti ve halkının sürekli bir işte çalışma konusundaki endişeleri olduğu düşünülmektedir. Söz konusu kötü şöhretin geçmişte yaşanan vakalardan çok önyargı ve tanımamaktan kaynaklandığı düşünülmektedir. Bunun yenilememesi halkın Göktaş d1şında sosyal, ekonomik ve kültürel iletişimi ve ilişkiyi kurmasını engellemektedir. Bundan yetişkinler kadar çocuklar da nasiplerini almakta ve en temel hakları olan eğitimden uzaklaşmaktadır. Göktaş'tan şu ana kadar hiç kimse üniversite bitirmemiş ve beyaz yakalı olarak tabir edilen işlerde çalışanı yoktur.

Yapılan görüşmelerden kamunun da gayretlerinin olduğu ve bu yönde hizmetlerin sağlandığı anlaşılmaktadır. Hatta, halkın tabiatıyla uygun olması itibariyle müzisyenlik kursları düzenlenmiştir. Ancak, süreç ve sonuçlar istenilen şekilde olmamıştır. Burada esas olarak daha katılımcı yöntemlerle Göktaş için projeler ve önlemler geliştirilirken Göktaş'ın doğru tanıtımı ve kötü şöhretinin ortadan kaldırılması ilk ve zorunlu bir adım olarak düşünülmektedir. Bunun sağlanması ile Göktaşlılar, genç nüfusları ve birlikte çalışma geleneklerinin güçlü olması özelliklerinden yararlanılarak, Eğirdir Gölü'ndeki olumlu gelişmeler doğrultusunda örgütlü bir şekilde tekrar su ürünleri faaliyetlerinde yer almaya yönelebilirler; peyzajın avantajlarından yararlanarak kırsal turizme yönlendirilebilirler.

Öte yandan, Eğirdir Gölü, içerisinde ve çevresinde barındırdığı biyolojik ve kültürel değerleri ile ender bulunan alanlardan biridir. Gölün barındırdığı canlı hayatının devamı, gölden faydalanan insanların yaşamlarını ve geleneksel yaşam biçimlerini devam ettirebilmeleri için gölün koruma - kullanma dengesine oturtulması gerekmektedir. Bunun için de en kısa zamanda gölün sürdürülebilir kullanımı yönünde, bütüncül bir yaklaşımla planlama ve uygulamalara ihtiyaç vardır. Bu alanların ekosistem içerisindeki işlevleri ve insanlar için faydaları sürdürülebilirlik prensipleri esas olarak alınmalıdır.

Uzun ve zorlu bir süreç olan kırsal kalkınma çalışmalarında farklı bileşenlerin doğru bir şekilde ortaya konulması önlemlerin geliştirilmesinde büyük önem taşımaktadır. Bunun için tarım ekonomisi alanında kullanılan klasik yöntemlerin yanı sıra ve/veya onlarla birlikte çok disiplinli ve geniş kapsamlı bir yöntem olan kültürel ekoloji yaklaşımının teşhis ve planlama için yararlı olacağı düşünülmektedir. 


\title{
EXTENDED ABSTRACT
}

\section{Cultural Ecology Approach in Rural Development: An Emprical Study in Göktaş District of Eğirdir Town of Isparta Province}

\author{
Şekibe Şanal - Fatma Handan Giray \\ Isparta University of Applied Sciences
}

The first name who used the term of cultural ecology as a methodology in order to comprehend how human adapts to such a large environment was Anthropologist Julian Steward. According to Steward, although it is possible to investigate cultural and social evolution only through the concepts such as culture, tradition and custom it is necessary to consider the forms of interactions with the environment where the people live and have relationships (Steward, 1972).

The cultural ecologic studies mostly deal with small communities because the basic concepts of cultural ecology approach such as ecology, harmony, types of livelihoods, environmental balance can be observed better in small societies. Following the related scientific literature, this study was carried out to analyse socio-economic structure of Göktaş neighbourhood of Eğirdir district in Isparta province through cultural ecology approach which discussed interactions between human and ecology with particular attention to effects of the changes in the Eğirdir Lake over time on residents of Göktaş in relation to the cultural texture of the neighbourhood. Although Göktaş is a rural area in terms of its characteristics, it has been a "neighbourhood" administratively during the study and became again a village through a ballot initiative in 2018.

Recently there are 384 habitants in Göktaş and the number of the households is 138 classified into two groups which are called "Abdal" (113 households) and Elekçi (25 households). Participatory observation and ethnographic method were used in the field study where the data gathered through a structured questionnaire formed based on the relevant cultural ecology literature and observations during regular visits paid to the neighbourhood for two years. One hundred eighteen of 138 households in the neighbourhood 
participated voluntarily in the interviews conducted within the scope of the research.

There are two important factors that determine the socio-economics of Göktaş, Eğirdir lake and Gypsies culture. The crayfish and fishing offered by the Eğirdir Lake, where Göktaş is located on the edge of it were the sources of livelihood for the study area from 1970 to 1985 . However, this employment and income has come to an end due to an infectious fungal disease appeared in the lake. Recently, people in Göktaş work on daily and temporarily base out of Göktaş for their livelihood. Mostly they perform music, employed in entertainment sector and/or apple harvesting, cold storage, fish process plants and the other daily agricultural and construction works. The main socio-economic and socio-cultural challenges they face are unemployment, immigration, fragmentation of families due to immigration and absence of a continues health centre and lack of socializing places. These are common challenges in all rural areas in the region. However, unlike other rural areas in the region, the biggest external problem of the people in Göktaş and its weakness is its bad reputation and prejudices in the region. As long as it does not overcome, it will not be possible for Göktaş people to establish an adequate social, economic and cultural communication and relationship other than Göktaş. It is thought that this reputation in question arises from prejudice and recognition, rather than past cases and it does not affect only adults but also children. As a result, children are moving away from education which is their most fundamental right. Nobody from Göktaş has ever get a university degree and has no employees in jobs called white collar.

It was determined during the study that there are willingness of the people of Göktaş and positive initiatives of the public authority.

It is understood from the interviews that the public institutes in the region also strives and services are provided in this direction for Göktaş. In fact, musicianship courses were organized in accordance with the nature of the local people. However, the process and results were not as desired. In order to avoid that in the future, it is suggested that while developing projects and measures for Göktaş with more participatory methods, the proper promotion and elimination of bad reputation of the area should be considered as a first and mandatory step.

Taking advantage of willingness of the people and positive initiatives of the public authorities together with the young population of Göktaş, strong 
traditions of working together, and amazing landscape, it is suggested for Göktaş to be re-involved in aquaculture activities and to plan rural tourism activities in an organized way and in line with the principles of sustainability.

In rural development studies, which is a long and challenging process, adequate combination of different components is important for developing proper measures. In order to achieve this, it is thought that applying the cultural ecology approach, which is a multidisciplinary and comprehensive method combining with the other conventional methods used by agricultural economists will be useful for diagnosis, planning and implementation.

\section{Kaynakça / References}

Akturan, U. (2007). Tüketici davranışına yönelik araştırmalarda alternatif bir teknik: etnografik araştırma. İstanbul Ticaret Üniversitesi Sosyal Bilimler Dergisi, 11, 237-252.

Arayıı, A. (2008). Avrupa'nın vatansızları çingeneler. Kalkedon Yayınları, 380s, İstanbul.

Arı, Y. (2003). Manyas Gölü’nün kültürel ekolojisi: tarihi süreçte adaptasyon ve değişim. Türk Coğrafya Dergisi, 40, 75-97.

Ateş, S., (2011). Julian Steward ve Karl Wittfogel ilişkisi: Antropolojik bir inceleme. Folklor/Edebiyat, 17(61), 127-140.

Butzer, K. W. (1994). Toward a cultural curriculum for the future: a first approximation, Rereading cultural geography. Kenneth E. Foot, et al. (Ed.). Austin: The University of Texas Press, 409-428.

Feyzioğlu, E. (2011). Ekoloji, din ve insan. Yüksek Lisans Tezi. Selçuk Üniversitesi Sosyal Bilimler Enstitüsü, Konya, 86.

Kışlalıŏlu, M. ve Berkes, N. (1990). Ekoloji ve çevre bilimleri. İstanbul: Remzi Kitabevi, 350.

Kocataş, A. (1997). Ekoloji ve çeore biyolojisi. Ege Üniversitesi Su Ürünleri Fakültesi Yayınları, İzmir, 564.

Kolukırı, S. (2005). Türk toplumunda çingene imgesi ve önyargısı. Sosyolojik Araştırmalar Dergisi, 8(2), 52-71.

Kolukırık, S. (2008). Türkiye'de Rom, Dom ve Lom gruplarının görünümü. Hacettepe Üniversitesi Türkiyat Araştırmalan Dergisi, 5, 143-153.

Kolukırı, S. (2009). Dünden bugüne çingeneler (kültür, kimlik, dil, tarih). İstanbul: Ozan Yayıncilık, 160.

Korkmaz, H. ve Gürbüz, M. (2008). Amik Gölü'nün kültürel ekolojisi. Marmara Coğrafya Dergisi, 17, 1-26. 
Steward, J. H. (1972). Theory of Culture Change: The Methodology of Multilinear Evolution, 244s, University of Illinois Press, Urbana.

Sutton, M. Q. ve Anderson, E. N. (2014). Introduction to cultural ecology. 419s, Lanham, AltaMira.

Türkiye İstatistik Kurumu. (2020). Adrese dayalı nüfus kayıt sistemi sonuçları. 15.1.2020 tarihinde https://biruni.tuik.gov.tr/medas/?kn=95\&locale=tr adresinden erişildi.

Ünaldı, H. (2012). Türkiye'de yaşayan kültürel bir farklılık: çingeneler. Batman Üniversitesi Yaşam Bilimleri Dergisi, 615-626.

\section{Kaynakça Bilgisi / Citation Information}

Şanal, Ş. ve Giray, F. H. (2020). Kırsal kalkınmada kültürel ekoloji yaklaşımı: Isparta İli Eğirdir İlçesi Göktaş Mahallesi uygulaması. OPUS-Uluslararası Toplum Araştırmaları Dergisi, 16(28), 1480-1507. DOI: 10.26466/opus.681887 